\title{
Effect of water temperature on infections with the microsporidian Enterocytozoon salmonis in chinook salmon
}

\author{
D. B. Antonio, R. P. Hedrick* \\ Department of Medicine and Epidemiology, School of Veterinary Medicine University of California, Davis, California 95616, USA
}

\begin{abstract}
The effect of water temperature on the progress of infections associated with Enterocytozoon salmonis Chilmonczyk, Cox, Hedrick 1991 was examined in chinook salmon Oncorhynchus tshawytscha after intraperitoneal injections of mononuclear leukocytes infected with the microsporidian parasite. Experimentally infected and control fish were held at water temperatures of $9,12,15,18$ and $21^{\circ} \mathrm{C}$ for $12 \mathrm{wk}$ and then one half of the exposed and control groups of fish at 9 and $12^{\circ} \mathrm{C}$ were shifted to $15^{\circ} \mathrm{C}$ and held for an additional 8 wk. Among fish held at constant water temperatures, severe infections occurred among exposed fish at 15 and $18^{\circ} \mathrm{C}$ resulting in $90.0 \%$ cumulative mortality in both groups. Disease and significant mortality was also observed at $21^{\circ} \mathrm{C}$ $(47.5 \%)$. The parasite and signs of the disease slowly developed over time at $12^{\circ} \mathrm{C}$ and the cumulative mortality reached $73.7 \%$ between 13 and $20 \mathrm{wk}$. Although the development of the microsporidian was not arrested at a water temperature of $9^{\circ} \mathrm{C}$, infections in chinook salmon were not severe and cumulative mortalities were low $(10.0 \%)$. However, parallel groups of exposed chinook salmon at $9^{\circ} \mathrm{C}$ which were shifted to $15^{\circ} \mathrm{C}$ showed a cumulative mortality of $60.0 \%$ by 8 wk after trans. fer to the higher water temperature. Shifting the exposed fish from 12 to $15^{\circ} \mathrm{C}$ did not increase the mortality rate from that of fish kept constantly at $12^{\circ} \mathrm{C}$. The control fish (not exposed to E. salmonis) in all temperature groups did not show signs of the disease nor mortality throughout the study.
\end{abstract}

KEY WORDS: Enterocytozoon salmonjs - Water temperature Chinook salmon - Microsporea

Enterocytozoon salmonis Chilmonczyk, Cox, Hedrick 1991 is an intranuclear microsporidian associated with a severe anemic condition in salmonid fish, particularly, chinook salmon Oncorhynchus tshawytscha (Hedrick et al. 1990, 1991, Baxa-Antonio et al. 1992). Spontaneous infections with the microsporidian have also been reported in steelhead trout O. mykiss (MacConnell et al. 1991) and among cultured populations of golden trout $O$. aquabonita and brook trout Salvelinus fontinalis ( $\mathrm{R}$. Hedrick unpubl. obs.)

-Addressee for correspondence
The progress of infection with the microsporidian has been described in chinook and kokanee salmon Oncorhynchus nerka (Hedrick et al. 1990, 1991). Earlier studies documented the occurrence of similar infections in chinook salmon raised in sea water or fresh water (Elston et al. 1987, Morrison et al. 1990). We have demonstrated transmission of the parasite and the progress of infections in chinook salmon held in fresh and sea water (Antonio \& Hedrick unpubl.)

Enterocytozoon salmonis has been successfully propagated in vitro using a newly developed culture medium (Wongtavatchai et al. 1994). Using parasites from in vitro cultures of infected leucocytes as an inoculum, the effect of infections on chinook salmon at 5 water temperatures was examined

Materials and methods. Juvenile chinook salmon (mean wt $20.0 \mathrm{~g}$ ) were acclimated for $14 \mathrm{~d}$ at water temperatures of $9,12,15,18$ and $21^{\circ} \mathrm{C}$ in $132 \mathrm{l}$ aquaria receiving flow through fish-pathogen-free well water. Fish at each temperature were divided equally into 3 groups of 20 . Fish were anesthetized with $50 \mathrm{ppm}$ tricaine methane sulfonate (Argent) and then 2 groups were inoculated intraperitoneally with Enterocytozoon salmonis (isolate CA-1)-infected leukocyte suspensions from in vitro cultures at approximately $0.2 \mathrm{ml} \mathrm{fish}^{-1}$. One group was injected in the same manner but only with an equal volume of culture medium.

Fish which succumbed to infection were examined for signs of the disease and presence of the parasite. The few fish remaining by $12 \mathrm{wk}$ post-injection (PI) at 15,18 and $21^{\circ} \mathrm{C}$ were sacrificed and examined for the presence of the microsporidian. Also, at $12 \mathrm{wk}$ one half of the exposed and control fish at 9 and $12^{\circ} \mathrm{C}$ were transferred to $15^{\circ} \mathrm{C}$ to evaluate the effects of higher water temperature on mortality for an additional $8 \mathrm{wk}$. The remaining groups at 9 and $12^{\circ} \mathrm{C}$ were not shifted and were also evaluated for parasite-specific mortality until termination of the study at $20 \mathrm{wk}$ PI. 
Parasites were detected by imprints made from the posterior kidney that were air dried, fixed with methanol, stained with May-Grunwald Giemsa (Sigma) and then examined with a light microscope. External pathology of infected salmon included occasional uni or bilateral exopthalmos or extreme gill pallor. Internal signs were moderate to severe swelling of the kidney, spleen and posterior intestine. Occasionally, ascites was observed in the peritoneal cavity of Enterocytozoon salmonis infected chinook salmon. Detection of typical signs combined with presence of the microsporidian within leukocyte nuclei in stained imprints were used as criteria for confirmations of parasitespecific mortality due to E. salmonis.

Differences in mortality between groups at $12 \mathrm{wk}$ PI were evaluated by the chi-squared test (Sokal \& Rohlf 1969). Mortality occurring at 15,18 , and $21^{\circ} \mathrm{C}$ after $12 \mathrm{wk}$ were not included for statistical analysis because the few fish remaining in these groups were sacrificed.

The procedure for the culture of infected leucocytes is described in detail by Wongtavatchai et al. (1994). Briefly, the spleen and kidney of chinook salmon experimentally infected with Enterocytozoon salmonis were aseptically removed and the mononuclear cells separated by Ficoll Paque (Pharmacia) density gradient centrifugation. These mononuclear cells, in which E. salmonis develops, were propagated in a medium (SL-1) supplemented with human recombinant interleukin-2 (HrIL-2) and polyclonal mitogens. After $10 \mathrm{~d}$ in culture at $20^{\circ} \mathrm{C}$, the leukocyte suspension contained $1 \times 10^{5}$ cells $\mathrm{ml}^{-1}$. Chinook salmon were then injected with $0.2 \mathrm{ml}$ of the cell suspension per $20 \mathrm{~g}$ body weight of fish. An examination of these cells in the suspension used for inoculation revealed a $25 \%$ level of infection (Wongtavatchai et al. 1994). Fish in control groups received an intraperitoneal injection of an equal volume of sterile culture medium.

Results. The effect of water temperature on mortality of chinook salmon following experimental infections with Enterocytozoon salmonis is shown in Table 1. There was no mortality among the control groups at any temperature during the study. There were significantly different effects of water temperature on the mortality among experimentally infected groups as analyzed at $12 \mathrm{wk}$ PI. Both the 15 and $18^{\circ} \mathrm{C}$ groups were significantly different from the 9 and $12^{\circ} \mathrm{C}(\mathrm{p}<$ $0.0001)$ and the $21^{\circ} \mathrm{C}(\mathrm{p}<0.01)$ groups. In comparisons of mortality between 13 and 20 wk there were no differences between the $9^{\circ} \mathrm{C}$ shifted to $15^{\circ} \mathrm{C}$, the $12^{\circ} \mathrm{C}$ shifted to $15^{\circ} \mathrm{C}$ or the fish kept continuously at $12^{\circ} \mathrm{C}$. A statistical comparison of the mortality data was not possible at $20 \mathrm{wk}$ PI among $15^{\circ} \mathrm{C}, 18^{\circ} \mathrm{C}$, and $21^{\circ} \mathrm{C}$ groups because the few fish that remained at $12 \mathrm{wk}$ PI had been previously sacrificed.

By 12 wk PI, fish from both the 15 and $18^{\circ} \mathrm{C}$ exposed groups suffered high cumulative mortalities $(90.0 \%)$. Mortalities occurred between 42 and $81 \mathrm{~d}$ at $15^{\circ} \mathrm{C}$ and between 33 and $60 \mathrm{~d}$ at $18^{\circ} \mathrm{C}$. Moribund and dead fish in these groups showed severe exopthalmos and extreme gill pallor. Internal signs included severe swelling of the kidney, spleen and posterior intestine and ascites was present in the peritoneal cavity. Of the fish remaining at $12 \mathrm{wk}$ that were sacrificed and exam-

Table 1. Oncorhynchus tshawytscha. Effect of water temperature on mortality of chinook salmon following intraperitoneal injections of Enterocytozoon salmonis (isolate CA-1)-infected mononuclear leukocytes $\left(5 \times 10^{3} \mathrm{cells} / \mathrm{fish}\right.$ ). Fish were held at the same temperature for $12 \mathrm{wk}$ and then half of the groups at 9 and $12^{\circ} \mathrm{C}$ were transferred to $15^{\circ} \mathrm{C}$ and examined for an additional 8 wk. Fish at 15,18 and $21^{\circ} \mathrm{C}$ were terminated at $12 \mathrm{wk}$ post infection

\begin{tabular}{|c|c|c|c|c|c|c|}
\hline & \multirow{2}{*}{$\begin{array}{c}\text { Temperature } \\
\left({ }^{\circ} \mathrm{C}\right)\end{array}$} & \multirow[t]{2}{*}{ Replicate } & \multicolumn{2}{|c|}{ No. dead fish/no total } & \multicolumn{2}{|c|}{ Mean \% mortality ${ }^{d}$} \\
\hline & & & 4 to $12 w k$ & 13 to $20 \mathrm{wk}$ & 4 to $12 \mathrm{wk}$ & 13 to $20 \mathrm{wk}$ \\
\hline \multirow[t]{10}{*}{ Same temperature } & 9 & 1 & $0 / 20$ & $2 / 10$ & $0.0 a^{\circ}$ & $10.0 \mathrm{a}$ \\
\hline & & 2 & $0 / 20$ & $0 / 10$ & & \\
\hline & 12 & 1 & $0 / 20$ & $7 / 10$ & $5.0 \mathrm{a}$ & $73.8 \mathrm{~b}$ \\
\hline & & 2 & $2 / 20$ & $7 / 9$ & & \\
\hline & 15 & 1 & $16 / 20$ & - & $90.0 \mathrm{~b}$ & - \\
\hline & & 2 & $20 / 20$ & - & & \\
\hline & 18 & 1 & $18 / 20$ & - & $90.0 b$ & - \\
\hline & & 2 & $18 / 20$ & - & & \\
\hline & 21 & 1 & $10 / 20$ & - & $47.5 \mathrm{C}$ & - \\
\hline & & 2 & $9 / 20$ & - & & \\
\hline \multirow[t]{4}{*}{ Shifted temperature } & 9 to 15 & 1 & & $5 / 10$ & & $60.0 \mathrm{~b}$ \\
\hline & & 2 & & $7 / 10$ & & \\
\hline & 12 to 15 & 1 & & $8 / 10$ & & $67.8 b$ \\
\hline & & 2 & & $5 / 9$ & & \\
\hline
\end{tabular}


ined for presence of the parasite 67 and $25 \%$ of the fish at 15 and $18^{\circ} \mathrm{C}$, respectively, were infected with the parasite. Fish in the $21^{\circ} \mathrm{C}$ group that were inoculated with the parasite suffered a $47.5 \%$ mortality by $12 \mathrm{wk}$ and of the fish sacrificed at this time only $5 \%$ were found to be infected by examining stained kidney imprints.

Exposed fish held continuously at $9^{\circ} \mathrm{C}$ did not succumb to infection until $110 \mathrm{~d}$ PI and cumulative mortality $(10.0 \%)$ at $20 \mathrm{wk}$ PI was low. External and internal pathology of infected fish were not as severe as those found in infected fish from the higher temperature groups $\left(15,18,21^{\circ} \mathrm{C}\right)$. Affected fish showed mild gill pallor and slightly swollen kidneys and spleens. The replicate groups at $9^{\circ} \mathrm{C}$ which were transferred to $15^{\circ} \mathrm{C}$ at $12 \mathrm{wk}$ PI, however, showed high cumulative mortalities $(60.0 \%)$ which were significantly different $(p<$ 0.0001 ) from the mortality in the fish held continuously at $9^{\circ} \mathrm{C}(10.0 \%)$.

Although cumulative mortalities reached $73.7 \%$ between 13 and $20 \mathrm{wk}$ among fish held constantly at $12^{\circ} \mathrm{C}$, the infections developed more slowly (duration of mortality: 81 to $132 \mathrm{~d} \mathrm{PI)} \mathrm{when} \mathrm{compared} \mathrm{to} \mathrm{infected}$ fish at 15 and $18^{\circ} \mathrm{C}$. Shifting a part of the $12^{\circ} \mathrm{C}$ group of exposed fish to $15^{\circ} \mathrm{C}$ during the course of infection (Table 1 ) resulted in a similar level of mortality $(67.8 \%$ ) when compared to those held continuously at $12^{\circ} \mathrm{C}$ $(73.7 \%)$.

Discussion. The optimum water temperature for the progress of infections with Enterocytozoon salmonis in chinook salmon occurred at 15 and $18^{\circ} \mathrm{C}$. Mortality was delayed at $12^{\circ} \mathrm{C}$, but with time infections became severe resulting in a cumulative mortality of $73.7 \%$ by $20 \mathrm{wk}$ PI. Moderate to severe infections and significant mortality occurred among exposed chinook salmon at $21^{\circ} \mathrm{C}$ between 4 and $12 \mathrm{wk}$. At the owest water temperature tested $\left(9^{\circ} \mathrm{C}\right)$, mortality due to E. salmonis was delayed, infections were mild, and only low grade mortality occurred.

Earlier studies in our laboratory have shown that experimental transmission of Enterocytozoon salmonis to chinook salmon by injection, feeding and cohabitation results in severe infections and mortality at water temperatures of 15 to $18^{\circ} \mathrm{C}$ (Hedrick et al. 1991, BaxaAntonio et al. 1992). In those studies, chinook salmon began dying at $53 \mathrm{~d}$ following intraperitoneal injection of cell suspensions from the kidney of infected fish (Hedrick et al. 1991). Mortality occurred among chinook salmon from 68 to $118 \mathrm{~d}$ after feeding infected tissues and at $120 \mathrm{~d}$ after cohabitation of noninfected fish and experimentally infected fish (Baxa-Antonio et al. 1992). In the current study, injections with infected mononuclear leukocytes from in vitro cultures induced signs of the disease and mortality in chinook salmon by $81 \mathrm{~d}$ PI at water temperatures of $12^{\circ} \mathrm{C}$. Further compar- ison of the dose of the inoculum in experimentally induced infections, while needed, is complicated by the crude enumeration of parasites. The concentration of parasites is based solely on the percent of infected cells in the inoculum, which may be considered an underestimate because it excludes extracellular spores which are known to be infectious (unpubl. obs.).

The effect of water temperature can be directly on the development of the parasite, on the immune response of the fish, or both. In infections with the flagellate Ichthyobodo necator in Atlantic salmon Salmo salar, Robertson (1979) suggested that environmental variables, including temperature, were of secondary importance to the immunocompetence and susceptibility of the host to the parasite. Immunodepression in winter flounder Pseudopleuronectes americanus injected with the microsporidian Glugea stephani was not affected by temperature or dosage of spores but was due, in part, to prostaglandins or leukotrienes secreted by the host (Laudan 1986a, b). Although the direct effects of water temperature on the parasite or immune response of the fish are unknown in our current study, a depression of both $B$ and $T$ lymphocyte-like activities occurs in chinook salmon following infection with Enterocytozoon salmonis (Wongtavatchai et al. 1994). This may in part explain the susceptibility of salmon and trout with E. salmonis infections to secondary pathogens and mortality as proposed for other parasitic infections (Woo 1992). Water temperatures between 8 and $13^{\circ} \mathrm{C}$ are considered ideal for rearing Pacific salmon (Wood 1968). These temperatures which overlap with the 2 lower temperatures examined in our study were suboptimal for E. salmonis infections when compared to 15 and $18^{\circ} \mathrm{C}$.

The effect of temperature directly on parasite development was stressed by Lom (1979), who proposed that in Trypanosoma spp. infections in fish the seasonal occurrence of the disease was the direct result of temperature requirements of the parasite. Studies are currently under way to determine the direct effects of temper-ature on Enterocytozoon salmonis as propagated in in vitro cultures.

Although the development of Enterocytozoon salmonis was slowed and mortality was low at $9^{\circ} \mathrm{C}$ in our study, infections and mortality among chinook salmon became severe after transfer of the host to a higher temperature $\left(15^{\circ} \mathrm{C}\right)$. Shifting a part of the $12^{\circ} \mathrm{C}$ group to a higher temperature $\left(15^{\circ} \mathrm{C}\right)$ failed to significantly increase mortality. This result suggests that, although a lag in the onset of mortality occurs at the lower temperature $\left(12^{\circ} \mathrm{C}\right)$, once infections have had time to progress a small upward shift in temperature (to $15^{\circ} \mathrm{C}$ ) has less influence on the final mortality.

Our experiments clearly show that even at relatively non-permissive temperatures $\left(9^{\circ} \mathrm{C}\right)$, infection occurs 
and once established can rapidly progress at more optimal temperatures. A similar resumption of development on the microsporidan Glugea stephani was observed at $28 \mathrm{~d}$ after the host, English sole Parophrys vetulus, was returned to a temperature of 19 to $20^{\circ} \mathrm{C}$ after a period of $42 \mathrm{~d}$ at $10^{\circ} \mathrm{C}$ (Olson 1981).

The development of the parasite and the presence of infections among exposed fish held in all the temperatures examined in our study suggest that Enterocytozoon salmonis can tolerate a wide range of water temperatures. Severe and lethal infections may occur in fish when water temperatures become optimal for development of the parasite $\left(15\right.$ to $\left.18^{\circ} \mathrm{C}\right)$ and may in part explain the greater frequency of more severe epizootics among trout and salmon in the warmer rearing conditions and conversely, the more prolonged chronic losses associated with salmon held at colder water temperatures.

Acknowledgements. This research was funded in part by the California Department of Fish and Game and the U.S. Department of Agriculture 93-37204-9342. Dr J Wongtavatchai kindly provided the infected mononuclear leukocytes used in the exposure studies.

\section{LITERATURE CITED}

Baxa-Antonio D, Groff JM. Hedrick RP (1992) Experimental horizontal transmission of Enterocytozoon salmonis to chınook salmon Oncorhynchus tshawytscha. J Protozool 39:699-702

Elston RA, Kent ML, Harrell LH (1987) An intranuclear microsporidium associated with acute anemia in chinook salmon. J Protozool 34:274-277

Hedrick RP, Groff JM, Baxa DV (1991) Experimental infections with Enterocytozoon salmonis Chilmonczyk, Cox, Hedrick (Microsporea): an intranuclear microsporidium from chinook salmon Oncorhynchus tshawytscha. Dis aquat Org 10:103-108

Hedrick RP, Groff JM, McDowell TS, Willis M, Cox WT (1990) Hematopoietic intranuclear microsporidian infections with

Responsible Subject Editor W. Körting, Hannover, Germany features of leukemia in chinook salmon. Dis aquat Org 8 : $189-197$

Laudan R, Stolen JS, Cali A (1986a) The immune response of a marine teleost Pseudopleuronectes americanus (winter flounder) to the protozoan parasite, Glugea stephani. J Vet Immunol 12:403-412

Laudan R, Stolen JS, Cali A (1986b) Immunoglobulın levels of the winter flounder (Pleuronectes americanus) and the summer flounder (Paralichthys dentatus) injected with the microsporidan parasite (Glugea stephani). Dev comp Immunol 10:331-340

Lom J (1979) Biology of the trypanosomes and trypanoplasms of fish In: Lumsden WHR, Evans DA (eds) Biology of the Kinetoplastida, Vol 2. Academic Press, New York, p 269-337

MacConnell E, Shaw T, Smith CE (1991) Naturally-occuring infection with intranuclear microsporidium Enterocytozoon salmonis in steelhead trout Oncorhynchus mykiss. In: 4th Annual AFS/FHS meeting - 32nd western fish disease conference, Newport, Oregon, July 31-August 3, 1991, p 17

Morrison JK. MacConnel E. Chapman PF. Westgard RL 11990 A microsporidium induced lymphoblastosis in chinook salmon (Oncorhynchus tshawytscha). Dis aquat Org 8 $99-104$

Olson RE (1981) Effects of low temperature on the development of the microsporidan Glugea stephani in English sole (Parophrys vetulus). J Wildl Dis 17:559-562

Robertson DA (1979) Host-parasite interactions between Ichtyobodo necator (Henneguy, 1883) and farmed salmonids. J Fish Dis 2:481-491

Sokal RS, Rohlf FJ (1969) Biometry: the principles and practice of statistics in biological research. Freeman, San Francisco

Wongtavatchai J, Conrad PA, Hedrick RP (1994) In vitro cultivation of the microsporidian: Enterocytozoon salmonis using a newly developed media for salmonid lymphocytes J Tiss Cult Meth 125-131

Wongtavatchai J, Conrad PA, Hedrick RP (1995) Effect of the microsporidian: Enterocytozoon salmonis on the immune response of chinook salmon. Vet Immunol Immunopathol (in press)

Woo PT (1992) Immunological responses of fish to parasitic organisms. Ann Rev Fish Dis 339-366

Wood JW (1968) Diseases of Pacific salmon, their prevention and treatment. State of Washington Department of Fisheries Hatchery Division, Olympia, p 2.1

Manuscript first received: October 13,1994

Revised version accepted: February 20, 1995 